http://heanoti.com/index.php/hn

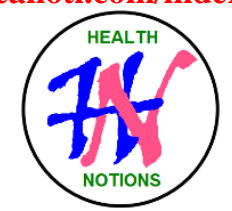

RESEARCH ARTICLE

URL of this article: http://heanoti.com/index.php/hn/article/view/hn30111

\title{
Psycho Religious in Nursing Care on DM Type 2 Patients Towards Depression and
} Blood Sugar Reduction

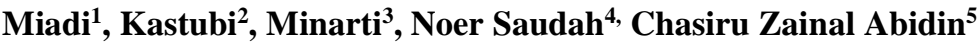 \\ ${ }^{1}$ Department of Nursing, Health Polytechnic of Surabaya, Indonesia; papaizzah@ gmail.com \\ ${ }^{2}$ Department of Nursing, Health Polytechnic of Surabaya, Indonesia; kastubi_ktb@ymail.com \\ ${ }^{3}$ Department of Nursing, Health Polytechnic of Surabaya, Indonesia; minartiivan@ gmail.com \\ ${ }^{4}$ Department of Nursing, Institute of Health Science "Bina sehat" of Mojokerto, Indonesia; \\ noersaudah15@gmail.com (Corresponding Author) \\ ${ }^{5}$ Islamic Education, Majapahit Islamic University of Mojokerto, Indonesia; cehazetabidin@gmail.com
}

\begin{abstract}
Effort to reduce depression and blood sugar levels through psycho religious of dzikir and shalawat was not carried out much yet. Research aims to explain psycho religious therapy effects towards depression and blood sugar level in Diabetes Mellitus type 2 patients (DM Type 2). This research used experimental method with randomized pre test post test control group design. This research was carried out on DM type 2 patients in Surabaya and they had been selected into two groups, given psycho religious group and control group. Blood sugar and depression measurement was carried out one week after and before psycho religious giving. Analysis data used Mann Whitney $\mathrm{U}$ test. While blood sugar concentration was analyzed using Paired t-test and Independent t-test. There was an effect of psycho religious towards depression of DM Type 2 patients, significant value of $0.004(p<0.05)$ and towards blood sugar level of patients, significant value of 0.474. DM type 2 patients who got psycho religious therapy had depression reduction but not with their blood sugar levels. Psycho religious need to be carried out to prevent severe depression. Further research are needed to be conducted which focus on duration and dose of psycho religious giving.
\end{abstract}

Keywords: Psycho religious, Depression, Diabetes Mellitus, Blood sugar level

\section{INTRODUCTION}

\section{Background}

Depression has risk to occur in DM patients. Depression that occurs in DM patients can cause blood sugar levels increment ${ }^{(1)}$. High blood sugar levels cause several organ damage such as eyes kidneys, nerve, heart and blood vessels ${ }^{(2)}$. Various efforts to reduce blood sugar levels has been carried out for example through diet program, routine exercise, pharmacological therapy by medicine and insulin intake but efforts to reduce depression and blood sugar levels through psycho religious of dzikir sholawat was not carried out much yet.

Incident rate of DM and risk to experience of depression are still high in worldwide. Sufferers of DM have risk to experience depression 1,80 times higher than non DM people. It is reach 329 million people, and the mortality rate reach 4,6 million in $2011^{(3)}$. The number of DM sufferers in Indonesia reach 6,6 million in 2011 and predicted to increase become 10,6 million people in 2030. DM sufferers in Surabaya reach 21.268 people in $2012^{(4)}$.

Neurotransmitter factor have role in depression occurrence mechanism. Norepinephrine and serotonin are two neurotransmitters that have the biggest role in depression pathophysiology. Depression cause body malfunction include hormones, immunities, and digestion. Depression cause glucogenesis mechanism so that blood sugar levels in DM patients are uncontrolled ${ }^{(5)}$. Blood sugar levels increment in DM patients can cause body cells problems and also disruption of blood flow to periphery as a result of macro vascular complications, so that inhibit wound recovery ${ }^{(6)}$.

DM care efforts need comprehensive approach includes bio-psycho-socio-spiritual. Religion or religiosity gives important role to hasten patients' rehabilitation in psychological care of patients who suffer physical illness. 
There is a strong relation between religiosity and self serenity. Religiosity pushes people to accept the reality, gets self serenity and guides people behaviour to more familiar with His God.

\section{Purpose}

Aim of this research is explaining the effects of psycho religious towards depression and blood sugar levels of DM type 2 patients who experienced depression.

\section{METHODS}

This research was experimental study using randomized pre test-post test control group design on DM patients who got psycho religious therapy. Population in this research was all DM type 2 patients are 66 DM Patients. Samples were chosen by consecutive sampling. The experiment units in this research were 9 patients of every group identified from secondary data on Pacar Keling Health Center Surabaya. The informed consent gaved based on research aims explanation. Blood levels and depression measurement was carried out two times, before psycho religion therapy and two weeks after psycho religious therapy. Psycho religious therapy was a sequence of dzikir and doa (prayers) by spelling "Al-Fatihah" 7 times then "istighfar" 100 times, also "Allahumma shalli 'ala Muhammad wa ali Muhammad" sholawat 100 times ("Ya sayyidi ya rasulullah" sholawat 1000 times) that conducted once per day. Depression variable change was analyzed using Mann Whitney U test and blood sugar levels was analyzed using Paired t-test, Independent t-test with value significant 0.05 .

\section{RESULTS}

\section{General Description of Research Place}

Patients used in this research were DM type 2 patients registered on Pacarkeling Health Center Surabaya. Medical diagnose type based on ICD X was in the following: DM patients with ICD E10.8 (DM Type 2 with insulin unspecific complication). Research data collecting process was carried out by investigating patients' data in Pacarkeling Health Center Surabaya data base and doing home visitation.

\section{General Data}

Almost half of the DM patients' ages were above 60 years $(38.8 \%)$. Ages in control group and treatment group were homogeneous with significant value of $0.680(\mathrm{p}>0,05)$.

Almost half of the DM patients' education background were elementary school (44,2\%). Education backgrounds in control group and treatment group were homogeneous with significant value of $0.851(p>0.05)$.

Most of the DM patients' sexes were female (61.2\%). Sexes in control group and treatment group were homogeneous with significant value of 0.851 ( $\mathrm{p}>0.05$ ). For details, DM patients' characteristics distribution ontreatment group and control group can be seen in Table 1.

Table 1. The distribution of demographic characteristics of patients

\begin{tabular}{|c|c|c|c|c|c|c|c|}
\hline \multirow{2}{*}{\multicolumn{2}{|c|}{ Patients' characteristic }} & \multicolumn{2}{|c|}{ Control group } & \multicolumn{2}{|c|}{ Treatment group } & \multicolumn{2}{|c|}{ Total } \\
\hline & & Fn & $\%$ & Fn & $\%$ & Fn & $\%$ \\
\hline \multirow{4}{*}{ Age } & 40-50 Years & 3 & 16.7 & 3 & 16.7 & 6 & 33.4 \\
\hline & 51-60 Years & 3 & 16.7 & 2 & 11.1 & 5 & 27.8 \\
\hline & $61-70$ Years & 3 & 16.7 & 4 & 22.1 & 7 & 38.8 \\
\hline & Total & & & & & 18 & 100 \\
\hline \multirow{5}{*}{$\begin{array}{l}\text { Education } \\
\text { Background }\end{array}$} & Elementary School & 4 & 22.1 & 4 & 22.1 & 8 & 44.2 \\
\hline & Junior High School & 1 & 5.55 & 1 & 5.55 & 2 & 22.1 \\
\hline & Senior High School & 2 & 11.1 & 3 & 16.7 & 5 & 27.8 \\
\hline & College & 2 & 11.1 & 1 & 5.55 & 3 & 16,65 \\
\hline & Total & & & & & 18 & 100 \\
\hline \multirow{3}{*}{ Sex } & Male & 3 & 16.7 & 4 & 22.1 & 7 & 38.8 \\
\hline & Female & 6 & 33.4 & 5 & 27.8 & 11 & 61.2 \\
\hline & Total & & & & & 18 & 100 \\
\hline
\end{tabular}


Table 2. Description of depression levels

\begin{tabular}{|c|c|c|c|c|}
\hline \multirow{3}{*}{ Depression } & \multicolumn{4}{|c|}{ Group } \\
\hline & \multicolumn{2}{|c|}{ Control } & \multicolumn{2}{|c|}{ Treatment } \\
\hline & Pre & Post & Pre & Post \\
\hline \multirow{2}{*}{ None } & 0 & 0 & 0 & 5 \\
\hline & 0 & 0 & 0 & $55.6 \%$ \\
\hline \multirow{2}{*}{ Mild } & 3 & 4 & 4 & 3 \\
\hline & $33.3 \%$ & $44.5 \%$ & $44.5 \%$ & $33.3 \%$ \\
\hline \multirow{2}{*}{ Average } & 1 & 2 & 3 & 1 \\
\hline & $11.1 \%$ & $22.2 \%$ & $33.3 \%$ & $11.1 \%$ \\
\hline \multirow{2}{*}{ Severe } & 5 & 3 & 2 & 0 \\
\hline & $55.6 \%$ & $33.3 \%$ & $22.2 \%$ & - \\
\hline \multirow{2}{*}{ Total } & 9 & 9 & 9 & 9 \\
\hline & $100 \%$ & $100 \%$ & $100 \%$ & $100 \%$ \\
\hline Sig & \multicolumn{2}{|c|}{0.299} & \multicolumn{2}{|c|}{0.006} \\
\hline Min & \multicolumn{4}{|c|}{ Pre $=2$ Post $=1$} \\
\hline Max & \multicolumn{4}{|c|}{ Pre $=4$ Post 4} \\
\hline Median & \multicolumn{4}{|c|}{ Pre $=3$ Post $=2$} \\
\hline Modus & \multicolumn{4}{|c|}{ Pre $=2$ Post $=2$} \\
\hline Sig Pre & \multicolumn{4}{|c|}{0.313} \\
\hline Sig Post & \multicolumn{4}{|c|}{0.004} \\
\hline
\end{tabular}

The results showed minimum score of depression before treatment was 2 and after treatment was 1 , indicated there was a depression levels reduction before and after the treatment. Mann Whitney U statistic test results obtained p-value of 0.299 (there was no difference of depression on control group before and after the treatment). While on treatment group, the p-value was 0.006 (there was a difference of depression on treatment group before and after the treatment where treatment group had lower depression levels or better compared with before being treated).

The results of Mann Witney U Test obtained p-value of 0.013 (there was no difference in depression variable between treatment group and control group on pre test). While in post test obtained significant value of 0.004 (there was a difference in depression variable between treatment group and control group).

\section{The Effect of Psycho Religious Therapy on Blood Sugar Levels}

Table 3. Description of blood sugar levels

\begin{tabular}{ccccc}
\hline \multirow{2}{*}{ Blood sugar levels } & \multicolumn{4}{c}{ Group } \\
\cline { 2 - 5 } & Pre & Post & Pre & Post \\
\cline { 2 - 6 } & 1 & 0 & 0 & 2 \\
\hline \multirow{2}{*}{120} & $11.1 \%$ & - & - & $22.2 \%$ \\
\hline \multirow{2}{*}{$>120$} & 8 & 9 & 9 & 7 \\
& $8.9 \%$ & $100 \%$ & $100 \%$ & $77.8 \%$ \\
\hline \multirow{2}{*}{ Total } & 9 & 9 & 9 & 9 \\
& $100 \%$ & $100 \%$ & $100 \%$ & $100 \%$ \\
\hline Mean & 207.67 & 264.84 & 265.78 & 224.67 \\
\hline SD & 54.461 & 54.299 & 128.948 & 108.212 \\
\hline Lavene's Test & \multicolumn{3}{c}{0.940} & \multicolumn{2}{c}{0.468} \\
\hline Sig. & \multicolumn{2}{c}{0.040} & \multicolumn{3}{c}{0.474} \\
\hline
\end{tabular}

The results showed that blood sugar levels in patients of control and treatment group were homogen, with p-value $>0.050$. The T-Test in the control group obtained significant value of 0.040 (there was a difference of blood sugar levels in the control group before and after treatment). The blood sugar levels of control group increased before and after treatment. While in the treatment group, p-value was 0.474 (there was no difference of 
blood sugar levels in the treatment group before and after treatment. The mean score of blood sugar levels in the control and treatment group showed high values $(>200 \mathrm{mg} / \mathrm{dl})$. Nominally, blood sugar levels in the treatment group did show a reduction after the intervention, but statistically that reduction was meaningless.

\section{DISCUSSION}

\section{The Effects of Psycho Religious Therapy on Depression Levels of DM patients}

There was difference of depression in the treatment group before and after treatment, which the group that received treatment had lower levels of depression or better than before being treated. The depression is a mood disease. A disease which more than just sadness or grief. Depression is one form of psychiatric disorders in mood (affective/mood disorder), which characterized by moodiness, sluggishness, lack of interest in life, feeling useless, hopeless, etc. ${ }^{(7)}$. The psycho religious therapy given to breast cancer patients can increase self efficacy and reduce depression levels ${ }^{(9)}$.

The condition of depression that experienced by the patient due to the more severe stressor psychosocial, discrimination surrounding communities, life expectancy is getting smaller, also the fear of death. Besides DM is already known by public with a variety of complications such as gangrene and blood sugar levels that difficult to control. In terms of age, DM patients used in this research were patients older than 40 years. According to the development, individuals in that age range start receive the change in his self and think positively about life, so with psycho religious therapy which focuses on religious activities such as dzikir and sholawat can lead to peace of mind and influence towards reduction of depression ${ }^{(8)}$.

\section{The Effects of Psycho Religious Therapy on Blood Sugar Levels of DM patients}

There was difference of blood sugar levels in the control group before and after treatment. The blood sugar levels of control group increased before and after treatment. While in the treatment group, significance value was of 0,474 meant that there was no difference of blood sugar levels in the treatment group before and after treatment. The blood sugar levels in the treatment group after treatment did show a reduction, but statistically that reduction was meaningless.

The factors that cause a increment in blood sugar levels in patients with DM are excessive consumption of food, less physical activity, deficiency of insulin and stress ${ }^{(9)}$. Depression in diabetes contributes to neurohormonal and neurotransmitter change that can affect the metabolism of glucose ${ }^{(10)}$.

Patients used in this research are patients who were at home with self-care by patients and families. It caused researcher difficulty control other variables that influential. The results of interview obtained data that showed some patients were less discipline in diet program and some patients were less regular in the consumption of drug or insulin. This condition caused change of blood sugar levels in each patients became uncontrolled.

\section{Limitation}

In this research, there were several things that cause limited course of the process and the results of research among others : 1) The differences of socio-economic status of patients and education of patients, this caused psychological differences on patients in receiving and resolving any problems. 2) Age, most patients who be the subject of this research were adults, so that the development of self-concept was in a condition to accept change in himself and think positively about life.

\section{CONCLUSION}

Psycho religious therapy affects the level of depression but has no effect on reduce blood sugar levels in patients with DM type 2. So it is recommended: 1) Psycho religious therapy necessary in patients with DM type 2 disease in order to prevent more severe depression. 2) Further research need to be conducted about giving psycho religious therapy in patients with DM type 2 disease relate with dose (duration and frequency of psycho religious therapeutic) and the magnitude of the effect on blood sugar levels and the quality of life of patients with DM type 2 .

\section{REFERENCES}

1. Murdiningsih DS. Effect of Anxiety on Blood Glucose Levels in Patients with Diabetes Mellitus in the Banyuanyar Health Center Surakarta Area (Pengaruh Kecemasan Terhadap Kadar Glukosa Darah Pada Penderita Diabetes Melitus Di Wilayah Puskesmas Banyuanyar Surakarta). Talenta Psikologi. 2013;2(2):180197

60 | Publisher: Humanistic Network for Science and Technology 
2. American Diabetes Association. Standards Of Medical Care In Diabetes-2010. Diabetes Care. 2010;33(1):1161.

3. International Diabetes Federation. Diabetes Evidence Demands Real Action From The Un Summit On NonCommunicable Diseases [Internet]. IDF. 2011 [cited 2012 Jan 18]. Available from: http://www.idf.org/diabetes-evidence-demands-realaction-un-summit-non-communicable-diseases

4. Dinkes Kota Surabaya. Surabaya City Health Profile in 2010 (Profil Kesehatan Kota Surabaya Tahun 2010). Surabaya: Dinas Kesehatan Kota Surabaya; 2010.

5. Darmono MR. Symptoms of Depression, Diagnosis of Brief Referral Mental Disorders From PPDGJ-II (Gejala Depresi, Diagnosa Gangguan Jiwa Rujukan Ringkas Dari PPDGJ-III). Jakarta: Department of Psychiatrics, FK-Unika Atmajaya. 2013.

6. Subandi. Integration of Psychotherapy in the Medical World (Integrasi Psikoterapi dalam Dunia Medis). National Seminar on Integration of Psychotherapy in Islamic and Medical Review. Malang: UMM; 2003.

7. Hawari D. Management of Stress, Anxiety and Depression (Manajemen Stres, Cemas dan Depresi). Jakarta: FKUI. 2001.

8. Jalaluddin. Religious Psychology (Psikologi Agama). Jakarta: PT Rajagrafindo Persada; 2002.

9. Kastubi. Improvement of Self Efficacy through Psychological Intervention in Cancer Patients Experiencing Depression in the Working Area of Pacar Keling Health Center Surabaya (Peningkatan Self Efficacy Melalui Intervensi Psikoreligi Pada Pasien Kanker Yang Mengalami Depresi di Wilayah Kerja Puskesmas Pacar Keling Surabaya). Surabaya: 2013.

10. Medved EM, Mottram P. Diagnosis of Depression in Elderly Patients. Mavis Advances in Psychiatric Treatment. 2009; 6:49-56. Available from: http://apt.rcpsych.org/cgi/reprint/6/1/49.pdf 